\title{
A staged approach with vincristine, adriamycin, and dexamethasone followed by bortezomib, thalidomide, and dexamethasone before autologous hematopoietic stem cell transplantation in the treatment of newly diagnosed multiple myeloma
}

\author{
C. S. Chim • A. K. W. Lie • E. Y. T. Chan • Y. Y. Leung • \\ S. C. W. Cheung $\cdot$ S. Y. T. Chan • Raymond Liang • \\ Y. L. Kwong
}

Received: 13 July 2009 / Accepted: 6 April 2010/Published online: 29 April 2010

(C) The Author(s) 2010. This article is published with open access at Springerlink.com

\begin{abstract}
Bortezomib-based regimens have significant activities in multiple myeloma (MM). In this study, we tested the efficacy of a total therapy with a staged approach where newly diagnosed MM patients received vincristine/adriamycin/dexamethsone (VAD). VAD-sensitive patients $(\geq 75 \%$ paraprotein reduction) received autologous hematopoietic stem cell transplantation (auto-HSCT), whereas less VAD-sensitive patients ( $<75 \%$ paraprotein reduction) received bortezomib/thalidomide/dexamethasone (VTD) for further cytoreduction prior to auto-HSCT. On an intentionto-treat analysis, a progressive increase of complete remission (CR) rates was observed, with cumulative CR rates of $48 \%$ after HSCT. Seven patients progressed leading
\end{abstract}

C. S. Chim $(\bowtie) \cdot$ A. K. W. Lie $\cdot$ S. Y. T. Chan $\cdot$ R. Liang $\cdot$

Y. L. Kwong

Department of Medicine, Queen Mary Hospital,

University of Hong Kong,

102 Pokfulam Road,

Hong Kong, China

e-mail: jcschim@hku.hk

E. Y. T. Chan · Y. Y. Leung

Department of Pathology and Clinical Biochemistry,

Queen Mary Hospital, University of Hong Kong,

102 Pokfulam Road,

Hong Kong, China

S. C. W. Cheung

Department of Radiology, Queen Mary Hospital,

University of Hong Kong,

102 Pokfulam Road,

Hong Kong, China to three fatalities, of which two had central nervous system disease. The 3-year overall survival and event-free survival were $75.1 \%$ and $48.3 \%$, respectively. Six patients developed oligoclonal reconstitution with new paraproteins. In the absence of anticoagulant prophylaxis, no patients developed deep vein thrombosis. The staged application of VAD+/-VTD/auto-HSCT resulted in an appreciable response rate and promising survivals. Our approach reduced the use of bortezomib without compromising the ultimate CR rate and is of financial significance for less affluent communities.

Keywords Staged approach · VAD · VTD · Survival · Oligoclonal reconstitution $\cdot$ CNS disease

\section{Introduction}

Multiple myeloma (MM) has a low possibility of cure. However, important therapeutic improvements have been made. Scheduled autologous hematopoietic stem cell transplantation (auto-HSCT) after initial cytoreduction has resulted in a complete remission/near-complete remission $(\mathrm{CR} / \mathrm{nCR})$ rate of about $20 \%$ [1], which translates into a benefit in overall survival (OS). Recently, the advent of targeted therapy such as bortezomib results in important advances in the treatment of MM. Bortezomib, a proteasome inhibitor that inhibits nuclear factor kappa $\mathrm{B}$ [2], leads to a $\mathrm{CR} / \mathrm{nCR}$ rate of $10 \%$ in heavily treated, refractory, and relapsing patients with $\mathrm{MM}[3,4]$. 


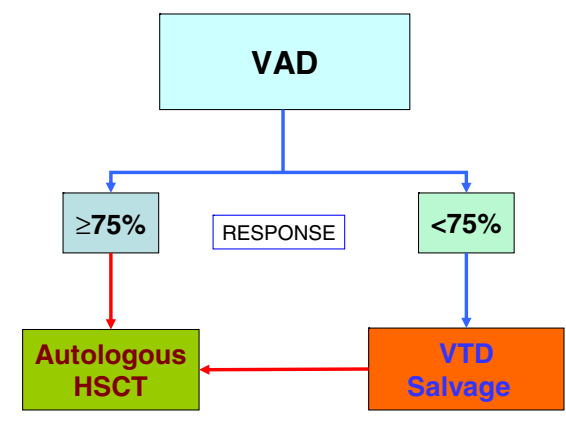

Fig. 1 Algorithm of patient treatment

Moreover, upfront use of bortezomib in combination with chemotherapy has resulted in a CR rate about of $20 \%$ (17$43 \%$ ) even in the absence of auto-HSCT [5, 6]. This is an important aspect in the management of $\mathrm{MM}$ as $\mathrm{MM}$ is a disease of the elderly, with the majority of the patients ineligible for auto-HSCT that leads to a high CR rate [1]. Furthermore, bortezomib is non-myelotoxic and hence may be used in combination with conventional chemotherapy. Indeed, synergism of tumor cytotoxicity has been demonstrated when chemotherapy is combined with bortezomib, thus restoring chemosensitivity to previously chemoresistant tumor cells [7, 8]. Based on these encouraging data, the upfront use of bortezomib in combination with conventional chemotherapy has been tested in younger patients before HSCT and in elderly patients who are not HSCT candidates. Expectedly, the upfront use of combined bortezomib and chemotherapy has resulted in a CR rate of about $20-30 \%$ in elderly patients [9] and a more encouraging $\mathrm{CR}$ rate of about $50 \%$ in younger patients when followed by auto-HSCT [10, 11]. The improved $C R$ rates have translated into superior progression-free survival and OS [12].

Both bortezomib and HSCT have emerged as important components in the management of MM, although their roles and timing relative to each other have not been determined. Bortezomib is an expensive medication with significant side effects. To optimally position bortezomib and HSCT, we reasoned that patients reaching a satisfactory response with conventional treatment might not need additional cytoreduction with bortezomib pre-HSCT. However, for patients with suboptimal response to conventional treatment, additional cytoreduction with bortezomib pre-HSCT might improve the outcome. Therefore, a staged approach was adopted in which newly diagnosed myeloma patients who achieved a $\geq 75 \%$ reduction in paraprotein level after standard vincristine, adriamycin, and dexamethasone (VAD) would proceed to auto-HSCT, whereas those with a $<75 \%$ paraprotein reduction would receive bortezomib, thalidomide, and dexamethasone (VTD) for additional cytoreduction prior to auto-HSCT.
Table 1 Patient demographics $(N=25)$

Ig immunoglobulin

International staging system [13]

Durie-Salmon staging system [14]

\begin{tabular}{ll}
\hline Median age (years, range) & 54 years $(33-65)$ \\
Male/female & $17 / 8$ \\
Paraprotein & $12(48 \%)$ \\
IgG & $4(16 \%)$ \\
IgA & $2(8 \%)$ \\
IgD & $7(28 \%)$ \\
Light chain & \\
Durie-Salmon stage & $2(8 \%)$ \\
IA & $4(16 \%)$ \\
IIA & $13(52 \%)$ \\
IIIA & $6(24 \%)$ \\
IIIB & \\
International staging system & $7(28 \%)$ \\
I & $7(28 \%)$ \\
II & $11(44 \%)$ \\
III & $4(19 \%)$ \\
DAPK methylation $(N=21)$ & $4.67 \mu \mathrm{g} / \mathrm{mL}(1.92-13.2 \quad \mu \mathrm{g} / \mathrm{mL})$ \\
Median $\beta_{2} \mathrm{M}(\mu \mathrm{g} / \mathrm{mL}$, range) & \\
Normal: $<1.42 \mu \mathrm{g} / \mathrm{mL}$ & $30 \mathrm{~g} / \mathrm{L}(17-49 \mathrm{~g} / \mathrm{L})$ \\
Median serum albumin $(\mathrm{g} / \mathrm{L}$, range) & $5.56 \times 10^{6}\left(\mathrm{range}: 2.88-20.4 \times 10^{6}\right)$ \\
Normal: $42-54 \mathrm{~g} / \mathrm{L}$ & $18(10-29)$ \\
Median CD34 positive cell dose/kg body weight &
\end{tabular}


Table 2 Cumulative response after each stage of treatment

\begin{tabular}{lllll}
\hline & Post-VAD $(N=25)$ & Post-VTD $(N=25)$ & 3-month post-Auto-HSCT $(N=25)$ & 3-month post-Auto-HSCT $(N=21)$ \\
\hline CR & $1(4 \%)$ & $2(8 \%)$ & $12(48 \%)$ & $12(57.1 \%)$ \\
nCR & $3(12 \%)$ & $4(16 \%)$ & $1(4 \%)$ & $1(4.8 \%)$ \\
VGPR & $4(16 \%)$ & $8(32 \%)$ & $5(20 \%)$ & $3(14.3 \%)$ \\
PR75 & $3(12 \%)$ & $9(36 \%)$ & $5(20 \%)$ & $5(23.8 \%)$ \\
PR50 & $5(20 \%)$ & 0 & 0 & 0 \\
MR & $6(24 \%)$ & 0 & 0 & 0 \\
NR & $3(12 \%)$ & $2(8 \%)$ & $2(8 \%)$ & 0 \\
\hline
\end{tabular}

$V A D$ vincristine, adriamycin, dexamethsone, $V T D$ velcade, thalidomide, dexamethasone, HSCT hematopoietic stem cell transplantation, $C R$ complete response, $n C R$ near-complete response, $V G P R$ very good partial response, $P R 75$ partial response with $75-90 \%$ paraprotein reduction, $M R$ minor response, $N R$ no response, $P R 50$ partial response with $50-75 \%$ paraprotein reduction

${ }^{\mathrm{a}}$ Intention-to-treat analysis

\section{Materials ad methods}

Patients, treatment algorithm, and protocol The study started in October 2005. The median follow-up time was 17 months (range, 7-39 months). Inclusion criteria were newly diagnosed $\mathrm{MM}$ with symptoms, age $<65$ years, measurable disease, serum creatinine $<3$ times the upper reference value (normal, $82-126 \mu \mathrm{mol} / \mathrm{L}$ ), and adequate liver function [15]. All patients received initial cytoreduction with three cycles of VAD. Those achieving $\geq 75 \%$ reduction in paraprotein proceeded to HSC mobilization with cyclophosphamide ( $4 \mathrm{~g} / \mathrm{m}^{2}$ intravenously) and granulocyte colony stimulating factor $(300 \mu \mathrm{g} /$ day subcutaneously unit leukocyte recovery). Patients with $<75 \%$ reduction in paraprotein received VTD (bortezomib, $1.3 \mathrm{mg} \mathrm{m}^{-2}$ day $^{-1}$ intravenously on days $1,4,8$, and 11 ; thalidomide, $200 \mathrm{mg} / \mathrm{day}$; and dexamethasone, $40 \mathrm{mg} / \mathrm{d}$ orally from days 1-4 and days 8-11). Thalidomide and bortezomib dosage was reduced to $75 \%$ for World Health Organization grade III toxicity and omitted for grade IV toxicity. Fourteen of the 25 patients proceeded to VTD salvage therapy because of $<75 \%$ reduction in paraprotein level. Of these 14 patients, all received four cycles of VTD, except one who had only three cycles of VTD due to grade IV neurotoxicity. Auto-HSCT conditioning regimen comprised intravenous melphalan at $200 \mathrm{mg} / \mathrm{m}^{2}$. Four patients did not receive auto-HSCT. Two patients opted for allogeneic HSCT with HLA-identical siblings, and they were censored after completion of VTD. The other two patients had primary refractory disease or rapidly progressive disease during VTD therapy. All patients received thalidomide (100-200 mg/day) as maintenance therapy regardless of whether VTD had been used. Prophylactic cotrimoxazole for Pneumocystis jirovecii was routinely prescribed. The protocol was approved by the institution review board in accordance with the Declaration of Helsinski, and informed consent was obtained from all participating patients. The treatment algorithm was shown in Fig. 1. Toxicity was reported after initial VAD and after VTD according to the Common Terminology Criteria for adverse events v3.0.

Staging and laboratory investigations MM workup included bone marrow examination, skeletal survey, serum $\beta_{2^{-}}$
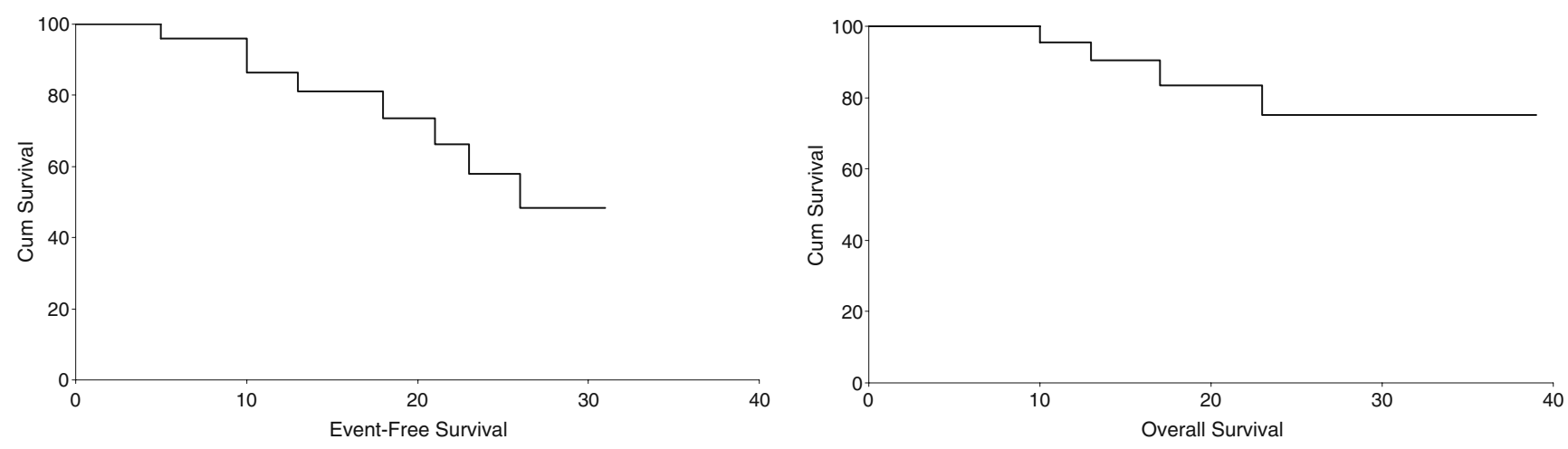

Fig. 2 Overall survival and event-free survival of 25 patients 
Table 3 Side effects after VAD and VTD

\begin{tabular}{|c|c|c|}
\hline After VAD & $\operatorname{VAD}(N=25)$ & $\operatorname{VTD}(N=14)$ \\
\hline Grade $3 / 4$ myelotoxicity & $10(40 \%)$ & 0 \\
\hline Sensory neuropathy (grade 2) & $12(48 \%)$ & $12(85.7 \%)$ \\
\hline Tremor & $2(8 \%)$ & $4(28.6 \%)$ \\
\hline Grade 1 & 2 & 3 \\
\hline Grade 3 & 0 & 1 \\
\hline Proximal muscle weakness & $2(8 \%)$ & $4(28.6 \%)$ \\
\hline Grade 2 & $1(4 \%)$ & 2 \\
\hline Grade 3 & $1(4 \%)$ & 2 \\
\hline Mucositis (grade 2) & $2(8 \%)$ & 0 \\
\hline Gastrointestinal & $3(12 \%)$ & $7(50 \%)$ \\
\hline Constipation & $2(8 \%)$ & 7 \\
\hline Grade 1 & 2 & 5 \\
\hline Grade 2 & 0 & 2 \\
\hline Epigastric pain & $1(4 \%)$ & 0 \\
\hline Deep vein thrombosis & 0 & 0 \\
\hline Infection/febrile episode & $7(28 \%)$ & $4(28.6 \%)$ \\
\hline Fever & 2 & 0 \\
\hline Hickman line infection & 2 & 0 \\
\hline HSV sacral ulcer & 1 & 0 \\
\hline Pneumonia/bronchitis & 1 & 1 \\
\hline CMV hepatitis & 1 & 0 \\
\hline Zoster & 0 & 1 \\
\hline Folliculitis & 0 & 1 \\
\hline Enterobactor & 0 & 1 \\
\hline Steroid-induced diabetes mellitus & $1(4 \%)$ & $1(7 \%)$ \\
\hline
\end{tabular}

$C M V$ cytomegalovirus, $H S V$ herpes simplex virus

microglobulin $\left(\beta_{2} \mathrm{M}\right)$ level, serum protein electrophoresis (SPE), urine protein electrophoresis, serum or urine immunofixation, paraprotein level assay, and serum free light chain (FLC) assay (Freelite, The Binding Site,
Birmingham, UK) [16]. All sera were assessed with SPE and FLC immunoassays. Urine was assessed for monoclonal FLC by immunofixation.

Response criteria All patients were analyzed on an intention-to-treat basis. Bone marrow plasmacytosis and paraprotein levels were assessed prior to treatment, after VAD, after VTD, and 3 and 6 months after auto-HSCT. Responses were defined according to standard criteria [17]. CR was defined as complete resolution of disease with absent paraprotein, as evidenced by a negative SPE and immunofixation, and $<5 \%$ plasma cells in the bone marrow. nCR was defined as a negative SPE but positive immunofixation. Partial response (PR) was sub-classified into very good partial remission (VGPR, paraprotein reduction $\geq 90 \%$ ), PR75 (paraprotein $\geq 75 \%$ but $<90 \%$ reduction), and PR50 (paraprotein $\geq 50 \%$ but $<75 \%$ reduction). Minor response (MR) was defined as paraprotein reduction of $\geq 25 \%$ but $<50 \%$. No response (NR) was defined as paraprotein reduction of $<25 \%$. Progression was defined as $\geq 25 \%$ paraprotein increase in two consecutive tests 4 weeks apart. Relapse was defined as reappearance of the paraprotein on immunofixation in $\mathrm{CR}$ patients, positive SPE in the nCR patients, and/or appearance of new bone lesions. For patients with lightchain MM (LCMM), CR was defined as normalization of the level and ratio of serum FLC and negative serum and urine immunofixation. Oligoclonal reconstitution was defined as the appearance of a new paraprotein not present at diagnosis, which persisted for $\geq 4$ weeks. Six of the patients developed a paraprotein different from that at diagnosis during $\mathrm{CR}$ or plateau phase and, hence, a "clonal change". However, the origin of the new clone was not clear and might imply development of a second malignancy entirely unrelated to the original disease. Therefore,

Table 4 Oligoclonal reconstitution in six myeloma patients

\begin{tabular}{|c|c|c|c|c|c|c|}
\hline Case & $\begin{array}{l}\text { Original } \\
\text { paraprotein }\end{array}$ & $\begin{array}{l}\text { New } \\
\text { paraprotein }\end{array}$ & $\begin{array}{l}\text { Paraprotein } \\
\text { level }\end{array}$ & $\begin{array}{l}\text { Time of onset of new } \\
\text { paraprotein }\end{array}$ & remark & Outcome \\
\hline $\mathrm{C} 1$ & K & IgGK & WQ & $\mathrm{CR}$ & Same light chain & $\begin{array}{l}\text { Persisted for } \\
11 \text { months }\end{array}$ \\
\hline $\mathrm{C} 2$ & $\lambda$ & $\operatorname{IgG} \lambda$ & WQ & $\mathrm{CR}$ & Same light chain & $\begin{array}{l}\text { Persisted } \times \\
4 \text { months }\end{array}$ \\
\hline $\mathrm{C} 3$ & $\operatorname{IgAK}$ & IgGK & & $\mathrm{CR}$ & Different heavy chain & $\begin{array}{l}\text { Persisted } \times \\
13 \text { months }\end{array}$ \\
\hline $\mathrm{C} 4$ & $\operatorname{IgD} \lambda$ & IgGK & $8 \mathrm{~g} / \mathrm{L}$ & $\mathrm{CR}$ & Different paraprotein & $\begin{array}{l}\text { Persisted } \times \\
5 \text { months }\end{array}$ \\
\hline $\mathrm{C} 5$ & IgGK & $\begin{array}{r}\text { double } \\
\text { IgGK }\end{array}$ & $2.1 \mathrm{~g} / \mathrm{L}$ & PR75 & Additional clone & $\begin{array}{l}\text { Persisted } \times \\
5 \text { months }\end{array}$ \\
\hline C6 & K & IgGK & $1.7 \mathrm{~g} / \mathrm{L}$ & $\mathrm{CR}$ & $\begin{array}{l}\text { A complete immunoglobulin with the } \\
\text { same light chain }\end{array}$ & $\begin{array}{l}\text { Persisted } \times \\
1 \text { month }\end{array}$ \\
\hline
\end{tabular}

$W Q$ too weak to quantitate, $C R$ complete remission, $P R 75$ partial response with $75 \%$ reduction in paraprotein 

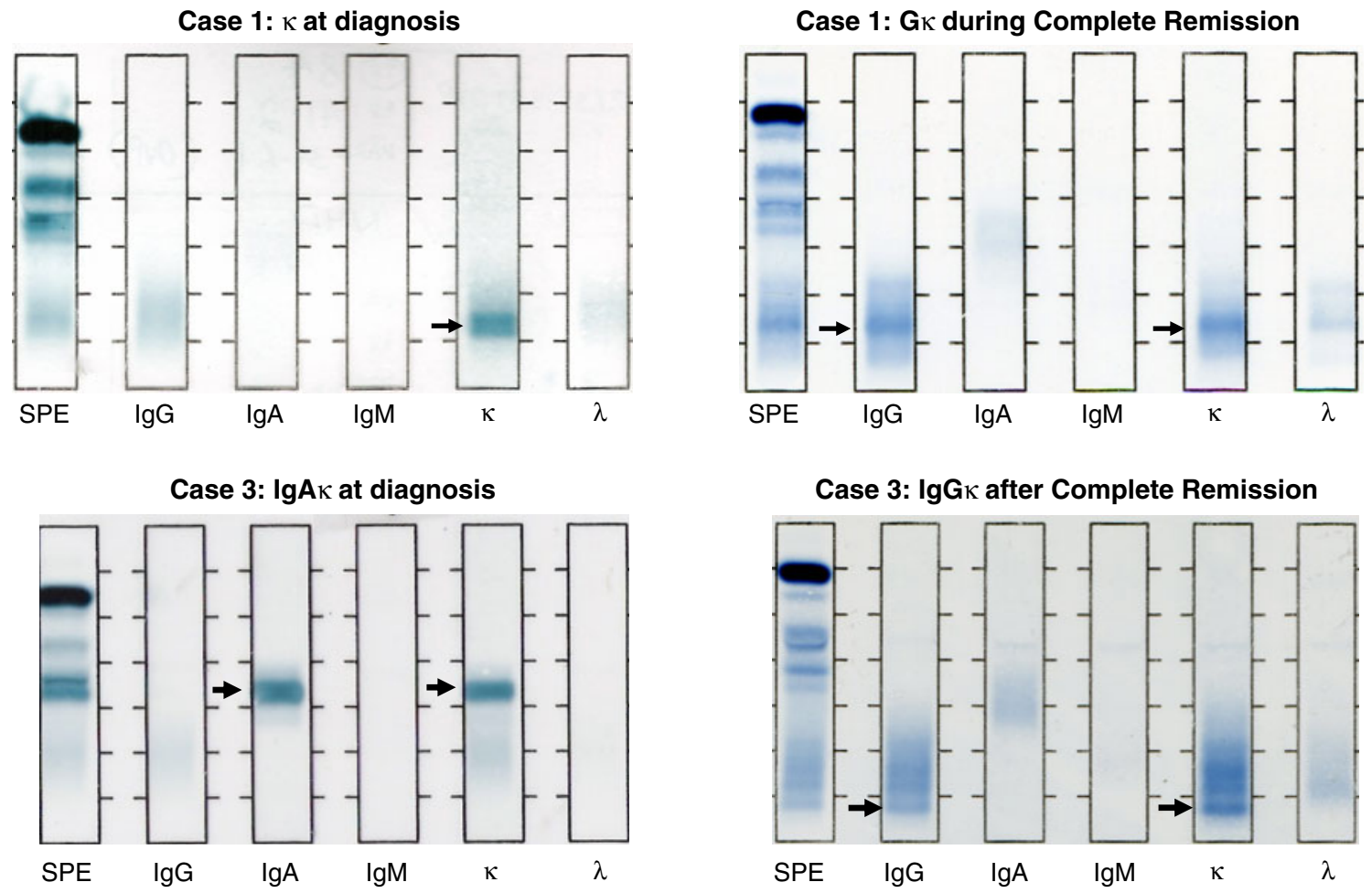

Case 4: $\lg \mathrm{D} \lambda$ at diagnosis

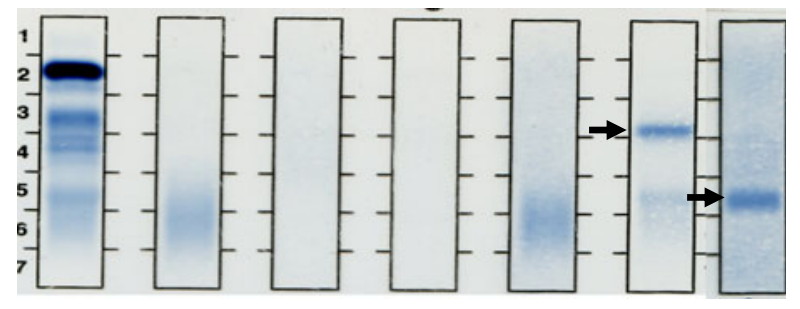

$\begin{array}{lllllll}\text { SPE } & \lg G & \lg \mathrm{A} & \lg \mathrm{M} & \kappa & \lambda & \lg \mathrm{D}\end{array}$

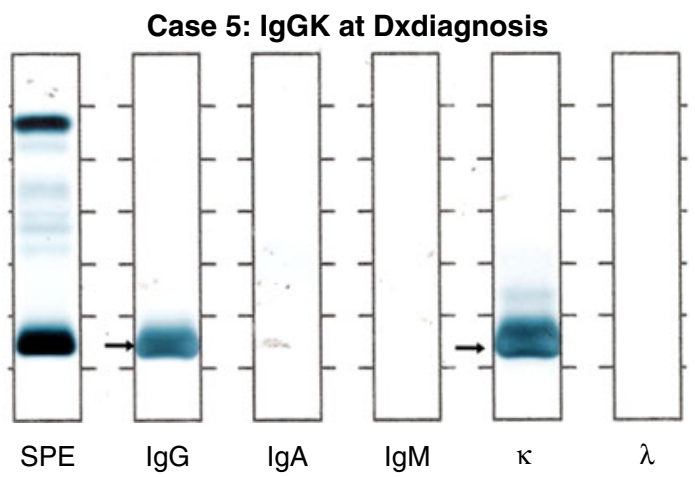

Fig. 3 Oligoclonal reconstitution in MM patients. Upper left showed clonal change of free kappa at diagnosis to IgGk during complete remission $(C R)$. Upper right showed clonal change from IgAK at diagnosis to IgGK during CR. Lower left showed clonal change from
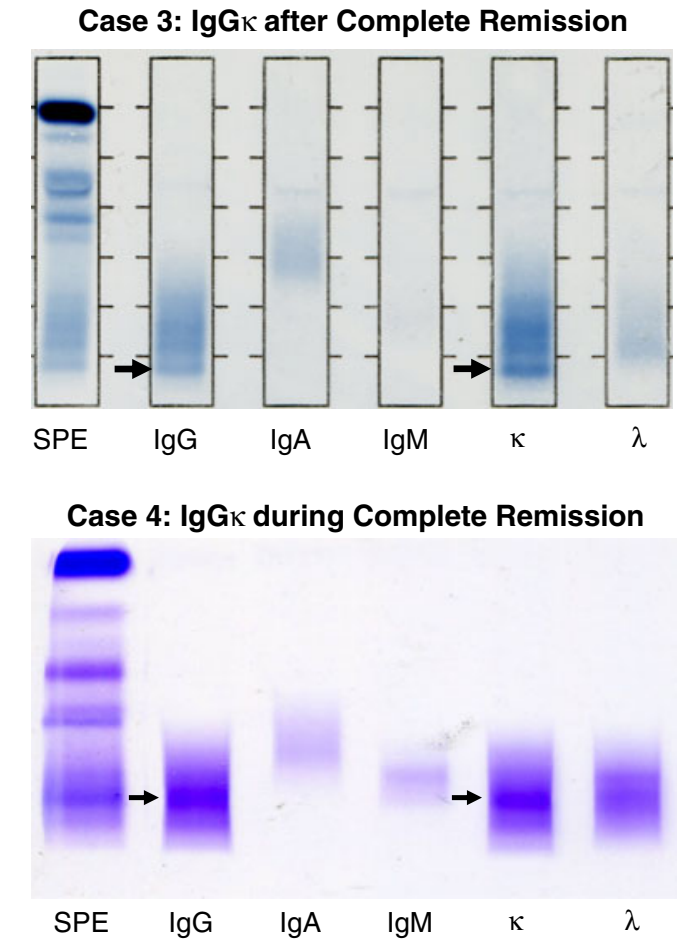

Case 5: double IgGK at diagnosis

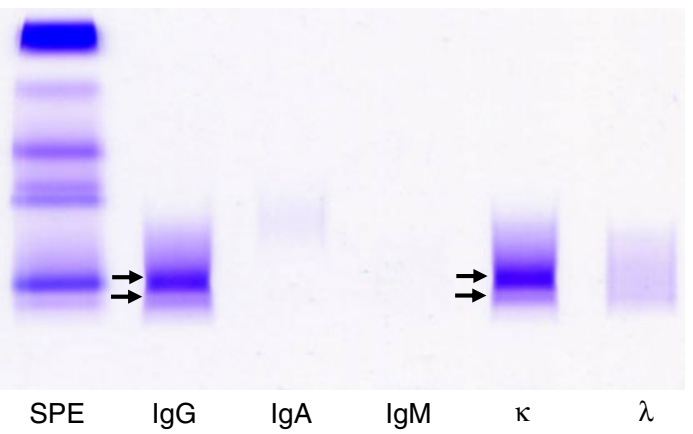

$\operatorname{IgD} \lambda$ (arrows) plus free $\lambda$ (arrowhead) at diagnosis to IgGk during CR. Lower right showed clonal change from single IgGK at diagnosis to double IgGk during $\mathrm{CR}$ 
Table 5 Characteristics and outcome of the seven patients with disease progression

\begin{tabular}{|c|c|c|c|c|c|c|c|c|}
\hline Patient & Paraprotein & $\begin{array}{l}\text { DS } \\
\text { stage }\end{array}$ & $\begin{array}{l}\text { ISS stage } \\
\text { at } \\
\text { Diagnosis }\end{array}$ & $\begin{array}{l}\text { Best } \\
\text { response }\end{array}$ & $\begin{array}{l}\text { Time from treatment } \\
\text { to progression } \\
\text { (months) }\end{array}$ & $\begin{array}{l}\text { Survival after } \\
\text { progression } \\
\text { (months) }\end{array}$ & Outcome & Site of progression \\
\hline $\mathrm{P} 1$ & Light chain & IIIA & III & $\mathrm{CR}$ & 10 & 3 & Death & $\begin{array}{l}\mathrm{BM}+\text { skin } \\
\text { plasmacytoma }+ \\
\text { circulating plasma cell }\end{array}$ \\
\hline $\mathrm{P} 2$ & $\operatorname{IgG}$ & IIIA & II & $\mathrm{CR}$ & 26 & $10+$ & $\begin{array}{c}\text { Alive with } \\
\text { disease }\end{array}$ & BM \\
\hline P3 & $\operatorname{IgG}$ & IIIA & II & PR75 & 13 & 4 & death & $\mathrm{CNS}+\mathrm{BM}$ \\
\hline $\mathrm{P} 4$ & $\operatorname{IgA}$ & IIIA & III & $\mathrm{CR}$ & 18 & 5 & death & Extramedullary + BM \\
\hline P5 & $\operatorname{IgG}$ & IIIB & III & $\begin{array}{c}\text { Progressive } \\
\text { disease }\end{array}$ & 5 & $8+$ & $\begin{array}{c}\text { Alive with } \\
\text { disease }\end{array}$ & Pleural \\
\hline P6 & $\operatorname{IgG}$ & IIIA & II & $\mathrm{CR}$ & 21 & 14 & $\begin{array}{c}\text { Alive with } \\
\text { disease }\end{array}$ & $\mathrm{BM}$ \\
\hline $\mathrm{P} 7$ & $\operatorname{IgG}$ & IIIA & II & VGPR & 23 & 16 & $\begin{array}{c}\text { Alive with } \\
\text { disease }\end{array}$ & $\mathrm{BM}$ \\
\hline
\end{tabular}

Ig immunoglobulin, $C R$ complete response, $P R 75$ partial response with $75-90 \%$ paraprotein reduction, $V G P R$ very good partial response, $B M$ bone marrow, CNS central nervous system

in the case of oligoclonal reconstitution, the absence of the original paraprotein by serum/urine immunofixation still qualified for CR.

Statistical analysis The primary endpoint was response rate. Secondary endpoints were survivals. OS was defined as time from commencement of induction therapy to death or last follow-up. Event-free survival (EFS) was defined as time from commencement of induction therapy to the date of progression, relapse, or death. Survival curves were plotted by Kaplan-Meier method.

\section{Results}

Patients The demographics of the patients were shown in Table 1. There was an incremental upgrade of response after each stage of treatment (Table 2). After VAD, 14 (56\%) proceeded to receive VTD. The CR rate was $4 \%$ after VAD, $8 \%$ after VTD, and $48 \%$ in an intention-totreat analysis after HSCT, or $57 \%$ for patients who actually completed HSCT. All patients undergoing autoHSCT had at least PR75 pre-HSCT. The projected 3-year OS was $75.1 \%$ (Fig. 2). Seven patients progressed, all having DS stage III disease with ISS stage II in four and stage III in three cases. The 3-year EFS was 48.3\% (median, 26 months; Fig. 2). Four patients died (all with DS stage IIIA disease), one of primary refractory disease, two of relapses after prior $\mathrm{CR}$, and one of progression from PR.
Side effects (Table 3)

After VAD, 12 (48\%) patients developed grade 2 sensory neurotoxicity, two $(8 \%)$ tremor (one grade 1 , one grade 2), three (12\%) with GI side effects (two grade 1 constipation, one epigastric pain), and seven (28\%) infective/febrile episodes. After VTD, $11(78.6 \%)$ had sensory neuropathy (grade $3, N=4$; grade $4, N=1$ ). Of these 11 VTD patients with sensory neuropathy, seven already had grade 2 sensory neuropathy after VAD, of which three had static grade 2 sensory neuropathy and four had increased severity of neuropathy (neuropathy increased from grade 2 to $3, N=3$, and grade 2 to $4, N=1$ ). Another four patients with no neuropathy after VAD developed neuropathy after VTD (grade 2, $N=3$; grade 3, $N=1)$.

Oligoclonal reconstitution Six patients developed oligoclonal reconstitution, five after $\mathrm{CR}$ (as defined by disappearance of the initial paraprotein; Table 4). Three patterns were observed. Cases 1, 2, and 6 with initially LCMM developed a complete immunoglobulin paraprotein. Case 5 developed an additional paraprotein with the same immunoglobulin subtype. Finally, cases 3 and 4 developed an entirely different paraprotein. For patients with a measurable new paraprotein, the level appeared to be stable over a period of 1-11 months (median, 5 months; Fig. 3).

CNS relapse Patient P4 (Table 5) with stage IIIA IgA MM achieved PR50 after VAD and CR with VTD. Acute spinal 
a

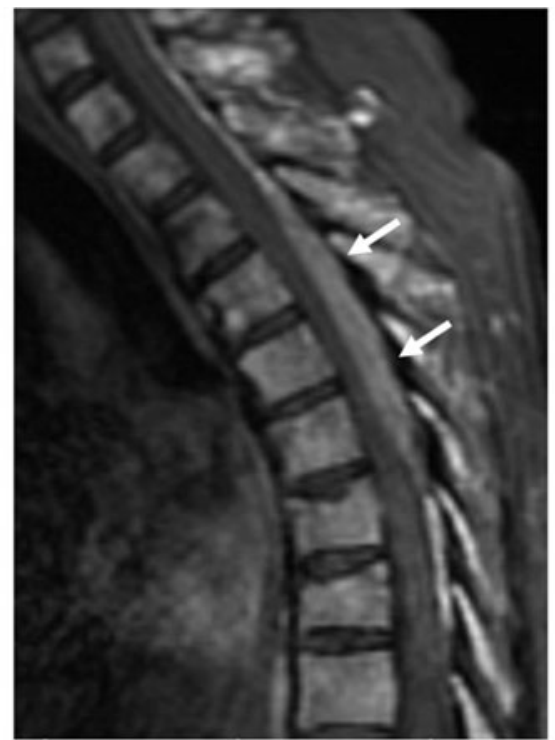

b

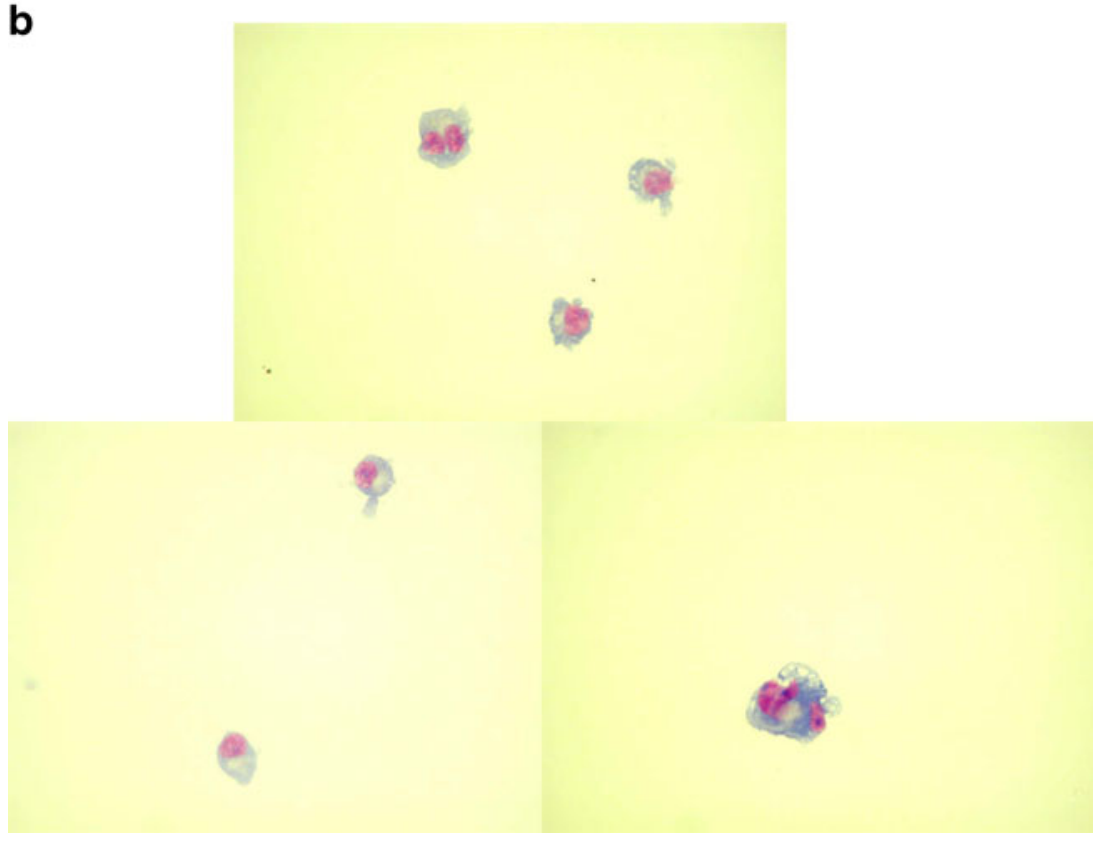

Fig. 4 a Sagittal fat-saturated SE T1W scan obtained after administration of intravenous gadolinium contrast agent showing an enhancing epidural mass (arrows) in the posterior spinal canal compressing the thoracic cord. b Cerebrospinal fluid showed myeloma cells

cord compression developed a year after HSCT, with IgA increasing to $2,020 \mathrm{mg} / \mathrm{dL}$ (normal $<386 \mathrm{mg} / \mathrm{dL}$ ). Magnetic resonance imaging showed an extensive thoraccolumbar extradural mass with cord compression (Fig. 4a). $\mathrm{He}$ achieved a partial response after bortezomib-CMP (cyclophosphamide, melphalan, and prednisolone) [8], but died of disease progression 2 months afterwards. Patient 3 with DS IIIA MM achieved PR75 after VAD, which was maintained with thalidomide after HSCT. Sudden diplopia due to right abducens nerve palsy and skin nodules developed 7 months after HSCT. Computerized axial tomography did not reveal any abnormality. The cerebrospinal fluid showed elevated protein $1.36 \mathrm{~g} / \mathrm{L}$ (normal <
$0.6 \mathrm{~g} / \mathrm{L})$ and a cell count of $52 \times 10^{6} / \mathrm{L}$ with $96 \%$ plasma cells (Fig. 4b). The serum paraprotein level resurged to $27 \mathrm{~g} / \mathrm{L}$. Bone marrow examination showed $28 \%$ pleomorphic plasma cells. He refused further treatment and died 4 weeks afterwards.

\section{Discussion}

In this study, the response to standard VAD was used to dichotomized patients to a chemosensitive group ( $\geq 75 \%$ paraprotein reduction after VAD) who proceeded directly to auto-HSCT and a relative chemoresistant group $(<75 \%$ 
paraprotein reduction) who received additional cytoreduction with VTD before auto-HSCT. We surmised that this staged approach might maximize the reduction of neoplastic cells prior to HSC mobilization and restrict the use of the expensive bortezomib to chemoresistant patients.

There are several interesting observations. We achieved a cumulative CR rate of $>50 \%$ after auto-HSCT. Recent studies showed that first-line use of bortezomib-based regimens gave $\mathrm{CR}$ rate of up to $30 \%$ even without $\mathrm{HSCT}$ [9]. Furthermore, total therapy using bortezomib-containing regimens for initial cytoreduction prior to auto-HSCT resulted in a CR rate of about $50 \%(43 \%$ to $56 \%)$ [1012]. Therefore, the results in this study provide an alternative method of achieving an appreciable CR rate with a reduced use of bortezomib. In less affluent countries or health care systems, our approach offers a means of alleviating the financial burden of bortezomib without compromising the overall treatment results of patients with MM.

Despite the relatively high CR rate after auto-HSCT in our cohort, it is noteworthy that the CR rate only changed from $4 \%$ to $8 \%$ when VTD was used in patients not responding optimally to VAD. These results contrasted that of the regimen (PAD, bortezomib, doxorubicin, dexamethasone) in untreated MM patients where the CR rate was around $25 \%$ after PAD alone [10, 11]. While these results could not be directly compared as different regimens were used on dissimilar patient populations, this disparity might be partially explained by the fact that only relatively chemoresistant patients received VTD in our study.

On the other hand, using VAD upfront resulted in very frequent $(48 \%)$ sensory neuropathy prior to VTD. Moreover, eight had new onset or increased severity of neuropathy after VTD. Therefore, it would have been more preferable to use $\mathrm{AD}$ instead of VAD to avoid excessive neuropathy without compromising the chemotherapy response prior to VTD.

On follow-up, a significant number of patients developed a new paraprotein distinct from the one at diagnosis. Indeed, development of isotypic change and oligoclonal bands has been reported in about $10 \%$ of MM patients undergoing HSCT [18]. The long-term outcome of these new clones remains to be determined. If these new clones represented expansion of minor subclones consequent to effective elimination of major clones, this phenomenon of oligoclonal reconstitution might become more common as more effective treatment becomes available. Alternatively, appearance of the new clone might represent clonal evolution from the original clone. Case 5 who developed two GK bands evolving from one GK at diagnosis might be explained by this mechanism. Whatever the pathogenesis, oligoclonal reconstitution affects the management of patients. Firstly, the diagnosis of CR may be difficult. In our case, we define $\mathrm{CR}$ as the absence of the original clone, and hence, the emergence of another clone does not alter the diagnosis of CR. Secondly, the long-term outcome of these new clones in our patients is yet to be defined, which might be transient [18].

Two of our patients developed central nervous system (CNS) myeloma at progression in addition to cutaneous deposition and plasma cell leukemia. This is a rare complication [19, 20], and the factors predisposing to CNS dissemination remain to be elucidated. However, it would have been ideal if clonal analysis of the CSF plasma cells had been performed.

Finally, deep vein thrombosis (DVT) did not occur in any of our patients despite the omission of prophylaxis. In Western patients, when thalidomide was combined with dexamethasone or chemotherapy, the risk of DVT might be increased to $10-27 \%$ [21]. Our observation concurred with another study showing a low incidence of DVT in a cohort of 85 Chinese MM patients receiving thalidomide [22]. Moreover, the incidence of DVT in Chinese has been shown to be much less frequent than Caucasian patients to the extent that prophylaxis is not a standard practice even in patients undergoing orthopedic surgery $[23,24]$. This disparity might at least be partially explained by the absence of factor $\mathrm{V}$ Leiden and prothrombin 20210 mutations, both hereditary thrombophilic tendencies prevalent in Caucasians, in the Chinese population $[25,26]$. Therefore, we believe that Chinese patients do not require prophylactic aspirin while receiving thalidomide.

In conclusion, our VAD-VTD/auto-HSCT algorithm resulted in a high response rate and promising survivals. This staged approach has significant financial implications in the treatment of MM.

Acknowledgement We thank Drs Joyce Chan, Bonnie Khoo, Herman Liu, Thomas Lau from Pamela Youde Nethersole East Hospital; Drs Dominic Yeung, M.F. Law, Candia Chan and L.G. Wong from Tuen Mun Hospital; Drs K.K. Lee, Joycelyn Sim, Vivien Mak and Sandy Ho from Princess Margaret Hospital, for their patient referral and management. We also thank Mr Edwin Leong for funding support of bortezomib.

Open Access This article is distributed under the terms of the Creative Commons Attribution Noncommercial License which permits any noncommercial use, distribution, and reproduction in any medium, provided the original author(s) and source are credited.

\section{References}

1. Attal M, Harousseau JL (2007) Role of autologous stem-cell transplantation in multiple myeloma. Best Pract Res Clin Haematol 20(4):747-759

2. Bharti AC, Shishodia S, Reuben JM, Weber D, Alexanian R, RajVadhan S, Estrov Z, Talpaz M, Aggarwal BB (2004) Nuclear 
factor-kappaB and STAT3 are constitutively active in $\mathrm{CD} 138^{+}$cells derived from multiple myeloma patients, and suppression of these transcription factors leads to apoptosis. Blood 103:3175-3184

3. Richardson PG, Barlogie B, Berenson J, Singhal S, Jagannath S, Irwin D, Rajkumar SV, Srkalovic G, Alsina M, Alexanian R, Siegel D, Orlowski RZ, Kuter D, Limentani SA, Lee S, Hideshima T, Esseltine DL, Kauffman M, Adams J, Schenkein DP, Anderson KC (2003) A phase 2 study of bortezomib in relapsed, refractory myeloma. N Engl J Med 348:2609-2617

4. Richardson PG, Sonneveld P, Schuster MW, Irwin D, Stadtmauer EA, Facon T, Harousseau JL, Ben-Yehuda D, Lonial S, Goldschmidt H, Reece D, San-Miguel JF, Blade J, Boccadoro M, Cavenagh J, Dalton WS, Boral AL, Esseltine DL, Porter JB, Schenkein D, Anderson KC (2005) Assessment of Proteasome Inhibition for Extending Remissions (APEX) Investigators. Bortezomib or high-dose dexamethasone for relapsed multiple myeloma. N Engl J Med 352:2487-2498

5. Bensinger W (2008) Stem-cell transplantation for multiple myeloma in the era of novel drugs. J Clin Oncol 26(3):480-492

6. San-Miguel J, Harousseau JL, Joshua D, Anderson KC (2008) Individualizing treatment of patients with myeloma in the era of novel agents. J Clin Oncol 26(16):2761-2766

7. Mitsiades N, Mitsiades CS, Richardson PG, Poulaki V, Tai YT, Chauhan D, Fanourakis G, Gu X, Bailey C, Joseph M, Libermann TA, Schlossman R, Munshi NC, Hideshima T, Anderson KC (2003) The proteasome inhibitor PS-341 potentiates sensitivity of multiple myeloma cells to conventional chemotherapeutic agents: therapeutic applications. Blood 101(6):2377-2380

8. Chim CS, Hwang YY, Pang C, Shek TW (2009) Restoration of chemosensitivity by bortezomib: implications for refractory myeloma. Nat Rev Clin Oncol 6(4):237-240

9. San Miguel JF, Schlag R, Khuageva NK, Dimopoulos MA, Shpilberg O, Kropff M, Spicka I, Petrucci MT, Palumbo A, Samoilova OS, Dmoszynska A, Abdulkadyrov KM, Schots R, Jiang B, Mateos MV, Anderson KC, Esseltine DL, Liu K, Cakana A, van de Velde H, Richardson PG, VISTA Trial Investigators (2008) Bortezomib plus melphalan and prednisone for initial treatment of multiple myeloma. N Engl J Med 359(9):906-917

10. Oakervee HE, Popat R, Curry N, Smith P, Morris C, Drake M, Agrawal S, Stec J, Schenkein D, Esseltine DL, Cavenagh JD (2005) PAD combination therapy (PS-341/bortezomib, doxorubicin and dexamethasone) for previously untreated patients with multiple myeloma. Br J Haematol 129(6):755-762

11. Popat R, Oakervee HE, Hallam S, Curry N, Odeh L, Foot N, Esseltine DL, Drake M, Morris C, Cavenagh JD (2008) Bortezomib, doxorubicin and dexamethasone (PAD) front-line treatment of multiple myeloma: updated results after long-term follow-up. Br J Haematol 141(4):512-516

12. Barlogie B, Anaissie E, van Rhee F, Haessler J, Hollmig K, Pineda-Roman M, Cottler-Fox M, Mohiuddin A, Alsayed Y, Tricot G, Bolejack V, Zangari M, Epstein J, Petty N, Steward D, Jenkins B, Gurley J, Sullivan E, Crowley J, Shaughnessy JD Jr (2007) Incorporating bortezomib into upfront treatment for multiple myeloma: early results of total therapy 3 . Br J Haematol 138(2):176-185

13. Greipp PR, San Miguel J, Durie BG, Crowley JJ, Barlogie B, Bladé J, Boccadoro M, Child JA, Avet-Loiseau H, Kyle RA, Lahuerta JJ, Ludwig H, Morgan G, Powles R, Shimizu K, Shustik C, Sonneveld
P, Tosi P, Turesson I, Westin J (2005) International staging system for multiple myeloma. J Clin Oncol 20(15):3412-3420

14. Durie BG, Salmon SE (1975) A clinical staging system for multiple myeloma. Correlation of measured myeloma cell mass with presenting clinical features, response to treatment, and survival. Cancer 36(3):842-854

15. Kyle RA, Rajkumar SV (2009) Criteria for diagnosis, staging, risk stratification and response assessment of multiple myeloma. Leukemia 23(1):3-9

16. Bradwell AR, Carr-Smith HD, Mead GP et al (2001) Highly sensitive, automated immunoassay for immunoglobulin free light chains in serum and urine. Clin Chem 47:673-680

17. Bladé J, Samson D, Reece D, Apperley J, Björkstrand B, Gahrton G, Gertz M, Giralt S, Jagannath S, Vesole D (1998) Criteria for evaluating disease response and progression in patients with multiple myeloma treated by high-dose therapy and haemopoietic stem cell transplantation. Myeloma Subcommittee of the EBMT. European Group for Blood and Marrow Transplant. Br J Haematol 102(5):1115-1123

18. Zent CS, Wilson CS, Tricot G, Jagannath S, Siegel D, Desikan KR, Munshi N, Bracy D, Barlogie B, Butch AW (1998) Oligoclonal protein bands and Ig isotype switching in multiple myeloma treated with high-dose therapy and hematopoietic cell transplantation. Blood 91(9):3518-3523

19. Fassas AB, Ward S, Muwalla F, Van Hemert R, Schluterman K, Harik S, Tricot G (2004) Myeloma of the central nervous system: strong association with unfavourable chromosomal abnormalities and other high-risk disease features. Leuk Lymphoma 45(2):291-300

20. Damaj G, Mohty M, Vey N, Dincan E, Bouabdallah R, Faucher C, Stoppa AM, Gastaut JA (2004) Features of extramedullary and extraosseous multiple myeloma: a report of 19 patients from a single center. Eur J Haematol 73(6):402-406

21. Palumbo A, Rajkumar SV, Dimopoulos MA, Richardson PG, San Miguel J, Barlogie B, Harousseau J, Zonder JA, Cavo M, Zangari M, Attal M, Belch A, Knop S, Joshua D, Sezer O, Ludwig H, Vesole D, Bladé J, Kyle R, Westin J, Weber D, Bringhen S, Niesvizky R, Waage A, von Lilienfeld-Toal M, Lonial S, Morgan GJ, Orlowski RZ, Shimizu K, Anderson KC, Boccadoro M, Durie BG, Sonneveld P, Hussein MA, International Myeloma Working Group (2008) Prevention of thalidomide- and lenalidomide-associated thrombosis in myeloma. Leukemia 22(2):414-423

22. Chan MH, Lau SM, Chen YT, Chan CC, Chan CH, Lam YK (2005) Thrombosis is uncommon in Chinese patients receiving thalidomide - experience in a regional hospital in Hong Kong. ASH Annual Meeting Abstracts 106, p 5149

23. Cheuk BL, Cheung GC, Cheng SW (2004) Epidemiology of venous thromboembolism in a Chinese population. Br J Surg 91(4):424-428

24. Chan YK, Chiu KY, Cheng SW, Ho P (2004) The incidence of deep vein thrombosis in elderly Chinese suffering hip fracture is low without prophylaxis: a prospective study using serial duplex ultrasound. J Orthop Surg (Hong Kong) 12(2):178-183

25. Chan WP, Lee CK, Kwong YL, Lam CK, Liang R (1998) A novel mutation of Arg306 of factor $\mathrm{V}$ gene in Hong Kong Chinese. Blood 91(4):1135-1139

26. Jun ZJ, Ping T, Lei Y, Li L, Ming SY, Jing W (2006) Prevalence of factor V Leiden and prothrombin G20210A mutations in Chinese patients with deep venous thrombosis and pulmonary embolism. Clin Lab Haematol 28(2):111-116 